\title{
CHANGES IN PHYSICAL AND CHEMICAL PROPERTIES OF CALCIC CHERNOZEM AFFECTED BY Robinia pseudoacacia AND Quercus robur PLANTINGS
}

\author{
VADYM GORBAN*, ARTEM HUSLYSTYI, OLEKSANDR KOTOVYCH, VOLODYMYR \\ YAKOVENKO
}

Department of Geobotany, Soil Science and Ecology, Faculty of Biology and Ecology, Oles Honchar Dnipro National University, Gagarin ave. 72, 49010, Dnipro, Ukraine; e-mail: gorvadym@gmail.com

${ }^{*}$ Author for correspondence

Abstract

Gorban V., Huslystyi A., Kotovych O., Yakovenko V.: Changes in physical and chemical properties of Calcic chernozem affected by Robinia pseudoacacia and Quercus robur plantings. Ekológia (Bratislava), Vol. 39, No. 1, p. 27-44, 2020.

Growth of forest plantations on soils causes changes in their properties. These changes, their behavior, and magnitude depend on the original soil characteristics and also on the effect of forest plantations being grown. In the steppe zone of Ukraine, Robinia pseudoacacia L. and Quercus robur L. are the woody species most widely used in planting of forest plantations on chernozem soil. Chernozem soil formed exclusively under zonal steppe vegetation and chernozem soil under Robinia pseudoacacia and Quercus robur plantations were studied in this work to analyze the changes in soil properties caused by growth of these tree species. Dry aggregate size distribution, density, particle density, total porosity, organic carbon content, cation exchange capacity, $\mathrm{pH}$ values, hydrolytic soil acidity and dry residue, and the available nitrogen, phosphorus, and potassium content were analyzed. The studies found that Robinia pseudoacacia and Quercus robur plantations contribute to an increase in the share of aggregates 2-1 mm in size, as well as formation of aggregate fraction $>10 \mathrm{~mm}$, which are completely absent in the Calcic chernozem developed under the steppe vegetation. An increase in the density and particle density, as well as a decrease in the total porosity values were observed under the influence of forest stands studied. This is more common with chernozem under Q. robur plantation. It was found that the carbon percentage decreased in chernozem under the influence of Robinia pseudoacacia growth (on average, $0.4 \%$ by a meter-deep layer), but under Quercus robur planting it increased (on average $0.3 \%$ by meter-deep layer). Effect of Robinia pseudoacacia plantings on chernozem was also manifested by a decrease in cation exchange capacity (on average, $11 \mathrm{cmol} / 100 \mathrm{~g}$ by a meter-deep layer). The growth of $R$. pseudoacacia and Quercus robur plantations results in decrease of $\mathrm{pH}$ values ( 0.2 by a meter-deep layer) and increase of hydrolytic soil acidity and dry residue in chernozem water extract. Effect of Robinia pseudoacacia planting leads to a decrease in carbon, nitrogen, and phosphorus content in chernozem. The change in chernozem properties under the influence of Quercus robur plantation is reflected in accumulation of these nutrients. Growth of Robinia pseudoacacia and Quercus robur plantations leads to a decrease in potassium reserves in chernozem, which may indicate its active uptake by these woody species. In general, Q. robur planting is characterized by a large positive effect on the physical and chemical properties of chernozem than Robinia pseudoacacia planting. The findings obtained serve as a ground for making a recommendation for growing Quercus robur plantations under climate conditions of the steppe zone of Ukraine in order to improve the zonal chernozems' state and fertility.

Key words: chernozem, dry aggregate size distribution, total porosity, soil organic carbon, forest plantation, steppe zone. 


\section{Introduction}

Land degradation is one of the most common and important problems in the modern age, on which human security will depend in the near future (Amundson et al., 2015; Webb et al., 2017). This problem is relevant for most countries worldwide (Chappell et al., 2019; Jiang et al., 2019; Wunder, Bodle, 2019). Land degradation is closely related to the possible consequences of climate changes observed nowadays (Bonfante et al., 2019; Netsvetov et al., 2018; Zhou et al., 2019).

In Ukraine, the most common processes of soil degradation are the following: losses of humus and nutrients, overconsolidation, acidification, waterlogging, water and wind erosion, contamination with radionuclides, pesticides, and other organic substances, heavy metals, and soil aridization (Medvedev et al., 2014).

Artificial afforestation is one of the most effective measures for ecological soil restoration, protection for them water and wind erosion, and soil fertility restoration to reduce soil and land degradation (An et al., 2010; Gu et al., 2019; Lal, 2004; Ritter et al., 2003). As a whole, native and artificial forests perform an effective protective function against degradation of soil cover, especially in limiting the loss of humus and in topsoil protection (Wiśniewski, Märker, 2019). Both local and introduced arboreal species can be used for afforestation (Li et al., 2012). To maximize the benefits of afforestation efforts, it is necessary to take into account the particularities of the tree species used as well as of the plantation age (Sun et al., 2018; Zhang et al., 2018). Tree species can influence biological, chemical, and physical properties of soils directly through their deep roots, as well as through litter quality and quantity (Day et al., 2010; Edmondson et al., 2014). Changes in soil properties after afforestation are different and they depend on previous land use and vegetation types (Guo, Gifford, 2002; Jobbagy, Jackson, 2000).

The study of pattern of changes in soil organic carbon content in Calcic chernozem caused by cultivation of woody plantations is very important in understanding the characteristics of absorption and release of greenhouse gases in conditions of the steppe zone of Ukraine. The intensity of soil organic carbon sequestration and its conservation in the soil depends on the complex interactions between climate, soil, woody species, and management, as well as on the chemical composition of leaf litter determined by the dominant woody species (Lal, 2005). Based on similar studies conducted in other countries, majority of the researchers concluded that forest planting in arable land leads to increase in carbon sequestration and nitrogen accumulation in soils (Foote, Grogan, 2010; Sauer et al., 2012; Ussiri et al., 2006). The maximum intensity of increasing carbon and nitrogen reserves was observed in upper soil horizons, to a depth of $55 \mathrm{~cm}$ (Clark, Johnson, 2011). It was noted that soil organic carbon sequestration increases with the planting age (Berthrong et al., 2012; Boussougou et al., 2010; Jiao et al., 2011). Coincidently, it has been observed that soil carbon loss may occur in the first decades after planting of tree species and is followed by a recovery stage of unknown duration (Bárcena et al., 2014). It was found that the carbon sequestration value is largely determined by the species composition within tree plantations (Gurmesa et al., 2013). At the same time, plantations from broad-leaved trees placed on the lands of previous native forests or pastures did not significantly affect soil carbon stocks, while pine plantations reduced soil carbon stocks by 12-15\% (Guo, Gifford, 2002; Paul et al., 2002).

A comprehensive study of vegetation and wildlife of steppe forests has shown the importance to enlarge the woodland territories for the benefit of biological diversity conservation 
(Baranovski et al., 2018; Brygadyrenko, 2014, 2015, 2016). However, today, the influence of forest vegetation on the stability of soil aggregates and soil physical and chemical properties remains insufficiently studied in the steppe regions (Zhang et al., 2018). On this basis, the purpose of our work was to study the pattern of changes in aggregate size distribution and some physical and chemical properties of Calcic chernozem under the influence of black locust (Robinia pseudoacacia L.) and common oak (Quercus robur L.) plantations in the national park "Samarskiy Bir", Ukraine.

\section{Material and methods}

\section{Site characteristics}

Field surveys were carried out on the territory of the national park "Samarskiy Bir" (Fig. 1) located within the southeastern part of the steppe zone of Ukraine (Novomoskovskiy rayon, Dnipropetrovsk oblast, Ukraine).

Site 1 was located within the virgin steppe land of watershed plateau (southeastern part of the Andreevka village, $48^{\circ} 45^{\prime} 36.9^{\prime \prime} \mathrm{N}, 35^{\circ} 27^{\prime} 40.5^{\prime \prime} \mathrm{E}$ ). Herbaceous vegetative cover was closed, consisting of Festuca valesiaca Schleich. ex Gaudin, Koeleria macrantha (Ledeb.) Schult., Thymus marschallianus Willd., Linum hirsutum L., Salvia nemorosa L., Artemisia austriaca Jacq., and other herbaceous plant species. Groundwater depth was about $40 \mathrm{~m}$.

Site 2 was laid on the watershed plateau (westward of Vsesviatske village, $48^{\circ} 45^{\prime} 27.6^{\prime \prime} \mathrm{N}, 35^{\circ} 29^{\prime} 33.4^{\prime \prime} \mathrm{E}$ ). Groundwater depth was $40 \mathrm{~m}$ below the ground surface. Forest stands were represented by Robinia pseudoacacia L. aged about 60 years. The average tree height was $4-6 \mathrm{~m}$ and the stem diameter was $10-12 \mathrm{~cm}$. Stand canopy density was 0.7. Type of tree planting was line. The drilling distance was $0.5 \mathrm{~m}$ and the distance between rows was $1 \mathrm{~m}$. Elytrigia repens $\mathrm{L}$., Poa angustifolia L., and Chelidonium majus L. predominate in the herbaceous cover, with a total coverage of about $60-70 \%$.

Site $3\left(48^{\circ} 45^{\prime} 27.0^{\prime \prime} \mathrm{N}, 35^{\circ} 30^{\prime} 09.5^{\prime \prime} \mathrm{E}\right)$ was located on a watershed plateau next to Site 2. Forest stand was represented by Quercus robur L., aged about 60 years. The average tree height was 7-9 $\mathrm{m}$ and the stem diameter was 10-14 $\mathrm{cm}$. Stand canopy density was 0.9 . Type of tree planting was line. Rows of oak trees were alternated with rows of shrubs: Acer tataricum L. and rarely Euonymus europaeus L. The distance between rows was $0.75 \mathrm{~m}$ and the drilling

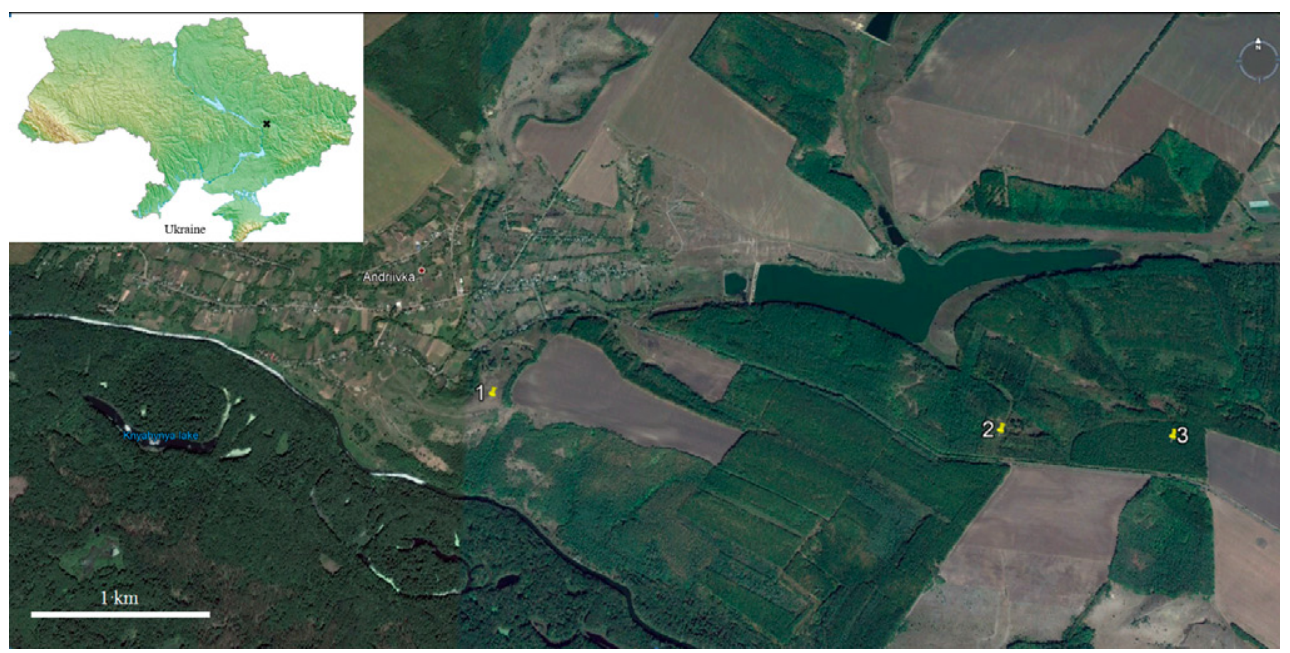

Fig. 1. Location of the sites in the territory of the National Park "Samarskiy Bir" (Novomoskovskiy rayon, Dnipropetrovsk oblast, Ukraine). 
distance was $1.5 \mathrm{~m}$. In the herbaceous cover, Elytrigia repens L., Verbascum lychnitis L., Salvia verticillata L., and Ajuga genevensis L. predominate, with a total coating of about $20-25 \%$.

\title{
Sample procedures
}

About $1 \mathrm{~kg}$ of the composite soil sample was selected on each of the three sites in the summer of 2017. Samples were taken from the middle of each 20 -cm layer, to a depth of $100 \mathrm{~cm}$. The soil samples selected were later used for laboratory determination of their structural and aggregative state and physical and chemical properties.

\section{Laboratory analyses}

Field description of soil profiles was carried out according to the guidelines for soil description (2006). Classification position of the studied soils was determined in accordance with the IUSS Working Group WRB 2015.

Air-dried soil samples were used in laboratory studies. Dry aggregate size distribution and physical and chemical soils properties were determined in accordance with the Soil Sampling and Methods of Analysis (Carter, Gregorich, 2008) recommendations. Aggregate size distribution of soils was determined by sifting of dry samples using a standard sieve set (mesh sizes $10,7,5,3,2,1,0.5$, and $0.25 \mathrm{~mm}$ ). The results of sieve analysis were expressed in terms of the percentage of the total weight of soil that passed through different sieves to the weight of total soil sample used for this analysis. Bulk density $\left(D_{b}\right)$ was defined as the weight of soil particles divided by the total soil volume. For this purpose, field soil samples of about $1000 \mathrm{~cm}^{3}$ each were taken with a hand probe, followed by weighing in the laboratory with parallel determination of field humidity. Particle density $\left(\mathrm{D}_{\mathrm{p}}\right)$ was determined using a glass pycnometer with a volume of $100 \mathrm{~cm}^{3}$ and $10 \mathrm{~g}$ of soil sample. The total porosity $S_{t}$ may be calculated using the particle density and bulk density values as $S_{t}=\left(1-D_{b} / D_{p}\right) \times 100$. Determination of soil organic carbon was based on the chromic acid wet oxidation method, wherein the soil oxidizable matter is oxidized by a solution of potassium bicarbonate $\left(\mathrm{K}_{2} \mathrm{Cr}_{2} \mathrm{O}_{7}\right)$ at a temperature of $140-150{ }^{\circ} \mathrm{C}$ with subsequent titration of the remaining dichromate with ferrous sulfate (Mohr's salt) $\left(\left(\mathrm{NH}_{4}\right)_{2} \mathrm{SO}_{4} \cdot \mathrm{FeSO}_{4} \cdot 6 \mathrm{H}_{2} \mathrm{O}\right)$. Available potassium and phosphorus were extracted with an acetic acid-based $\left(0.5 \mathrm{~mol} / \mathrm{dm}^{3}\right)$ chemical extractant at a soil-to-solution ratio of 1:25. Available potassium was determined by flame photometry method using flame photometer PFP-7/S; amount of available phosphorus was determined with molybdenum blue phosphorus method. Easily hydrolyzable nitrogen was determined with Kornfield method based on the hydrolysis of the soil organic compounds with an alkali solution $\left(\mathrm{NaOH}-1 \mathrm{~mol} / \mathrm{dm}^{3}\right)$ in Conway vessels. As a result of hydrolysis, nitrogen in the form of $\mathrm{NH}_{4}$ $+\mathrm{NO}_{3}$ obtained from diffusion was absorbed by a solution of boric acid and was determined by titration with a sulfuric acid solution. Determination of potential cation exchange capacity was carried out in accordance with the international standard ISO 13536: 1995, IDT in buffered barium chloride extracts using triethanolamine, $\mathrm{pH}$ $=8.1$. Unreacted magnesium was determined using atomic absorption spectrophotometer C-115 at a wavelength of $285.2 \mathrm{~nm}$. Determination of water $\mathrm{pH}$ was carried out in an aqueous extract prepared at a 1:5 soil to water ratio after 5-minute shaking. In the same extract, the total amount of water-soluble substances was determined with conductometric method using EZODO-7021.

\section{Statistical analysis}

Data obtained were analyzed with Statistica 6.0 (StatSoft Inc., 2012, Tulsa, OK, USA). Data were tabulated as x \pm standard deviation $(\mathrm{x} \pm \mathrm{SD})$. The differences between the control and experimental group values were determined using the Tukey test, where the differences between the samples were considered significant at $p<0.05$ (taking into account the Bonferroni correction).

\section{Results and discussion}

\section{Effect of tree plantations on the morphological structure of genetic horizons of Calcic chernozem}

\author{
The soil studied was characterized by uniformity of morphological structure along the profile
} (Table 1). 


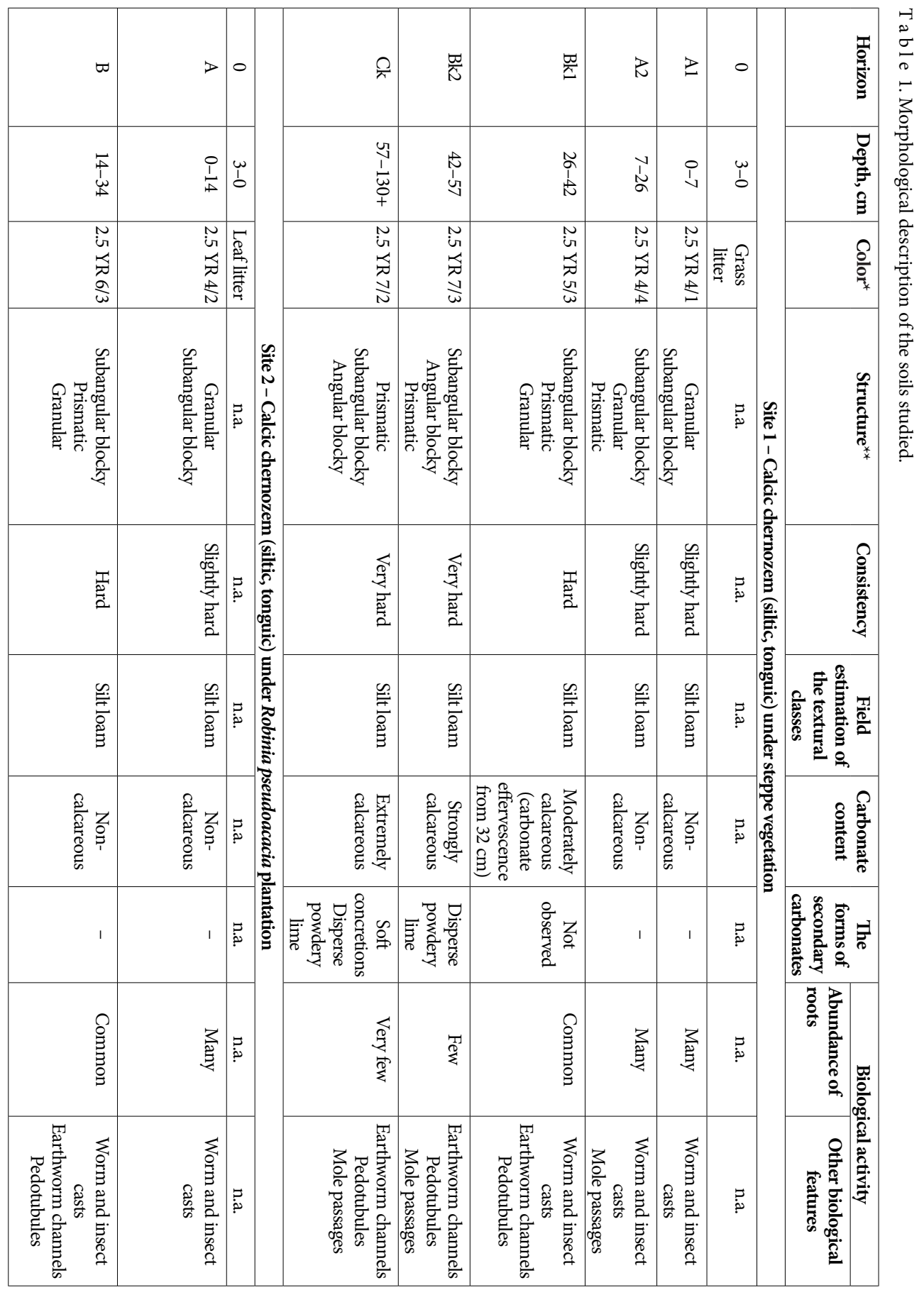




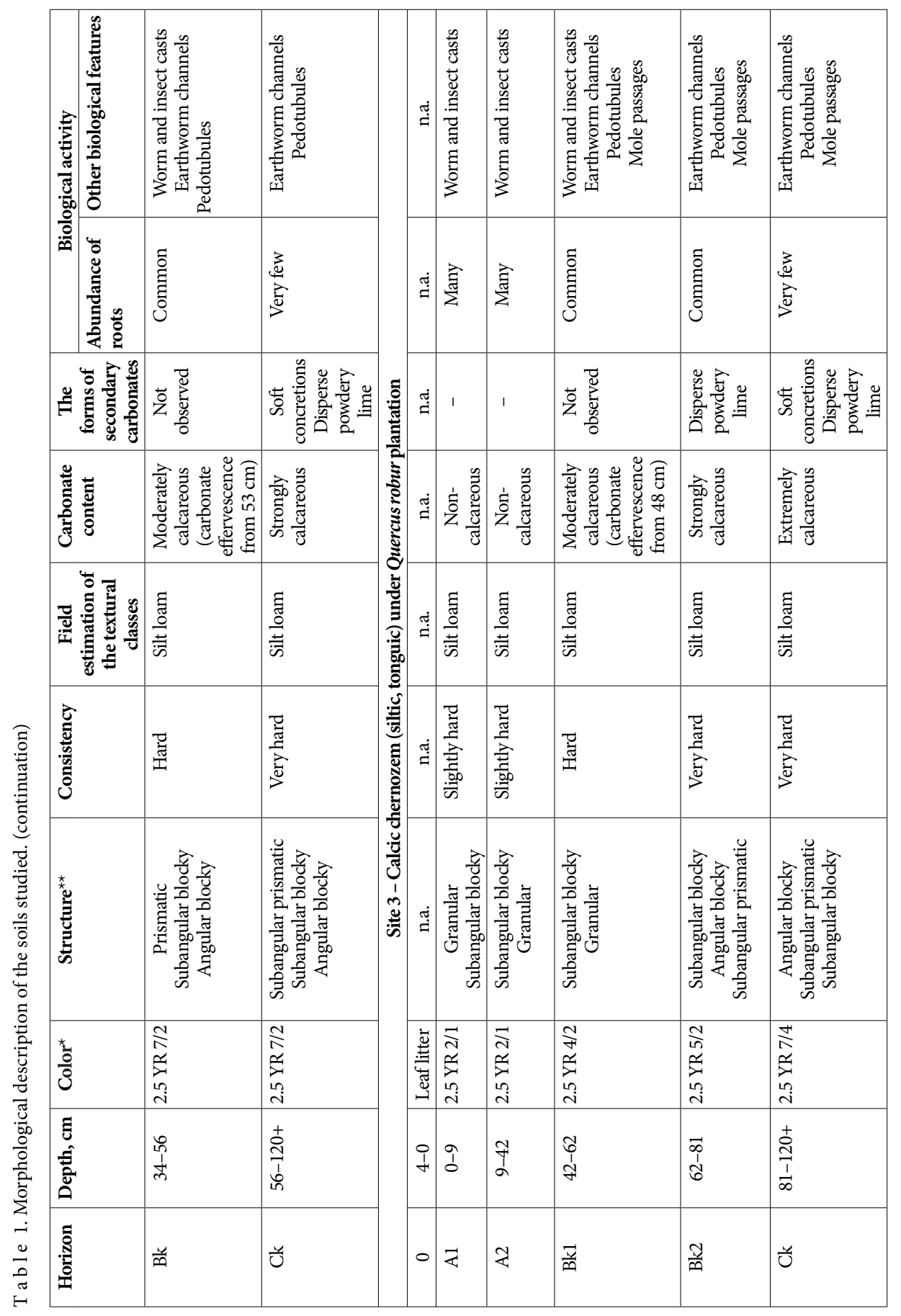

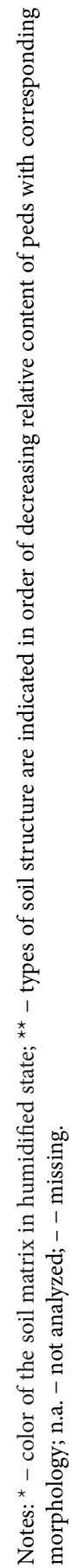


Granulometric composition throughout the profile showed presence of silt loam. The consistency of the soil material varied from slightly hard in the surface horizons A to very hard in the parent loess rock $\mathrm{Ck}$.

Surface horizons were characterized by granular and subangular blocky structure with a predominance of granular peds in horizon A1 and subangular blocky structure in horizon A2. In subsoil, the dominant types of structure were angular blocky structure, prismatic, subangular prismatic, and subangular blocky structure.

In the A horizons, carbonate neoformation was not observed. The Bk1 horizons were medium carbonated by the intensity of carbonate effervescence; however, the neoformations as a morphological element were not found. The Bk2 horizons were highly carbonated, and morphologically, neoformations had the form of disperse powdery lime. The subsoil was highly carbonated with a significant share of powdery precipitates and soft concretions. The spots were irregular shaped; they had diffuse boundaries and various concentrations of calcite crystals - from the crystals slightly visible on the general background of the soil material to predominance of whitish color.

Biological activity was most pronounced in the intensive root growth of herbaceous and woody plant species, with signs of invertebrate and vertebrate life activity on the soil structure and pore space. Maximum root content of herbaceous plant species was observed in surface horizons A; their quantity decreased in Bk horizons, and in Ck horizons the roots occurred in small quantity. Roots of woody plant species were developed at full depth of soil profile under the plantations of Robinia pseudoacacia and Quercus robur. In horizons A, a significant part of granular aggregates was represented by earthworm and insect larvae casts. Against the background of a more compact texture of Bk horizons, life activity of invertebrates was evident as a system of holes, much of which were filled with casts and structureless material (pedotubules). Similar signs were observed in the subsoil horizons, but to a smaller extent.

Sites 1 and 3 were located in the zone of mole rats (Spalax microphthalmus) activity. Mole passages were found across the whole profile. Within the humus-accumulative horizons A, the mole passages were filled mainly with loess parent material; in the lower part of the profile, the passages were filled with dark-colored humic material. Bulk density in the mole passages varied depending on their age; but generally, this parameter was less than the density of the parent material in the enclosing horizons. The boundaries between the mole passages and the enclosing material were from sharp to diffuse.

\section{Effect of forest plantations on aggregate size distribution in Chernozem}

Soil aggregate size distribution is an important characteristic closely related to the soil organic carbon content (Chaplot, Cooper, 2015; Polláková et al., 2018; Six et al., 2004); therefore, it may serve as a specific indicator of the intensity and duration of forest plantations' effect on the soil (An et al., 2010; De Carvalho Silva Neto et al., 2016; Jiang et al., 2019; Zhang et al., 2018).

Results of the study showed that the aggregate fraction of size $2-1 \mathrm{~mm}$ was predominant in the layers of $0-20$ and $20-40 \mathrm{~cm}$ of all soils studied. Moreover, the maximum content of such a fraction $(25.5 \%)$ in the layer $0-20 \mathrm{~cm}$ was in chernozem under black locust plantation, and the minimum (20.0\%) was found in chernozem under steppe vegetation (Fig. 2a). In the layer of $20-40 \mathrm{~cm}$, the maximum content of 2-1 mm aggregate size fraction (26.2\%) was 

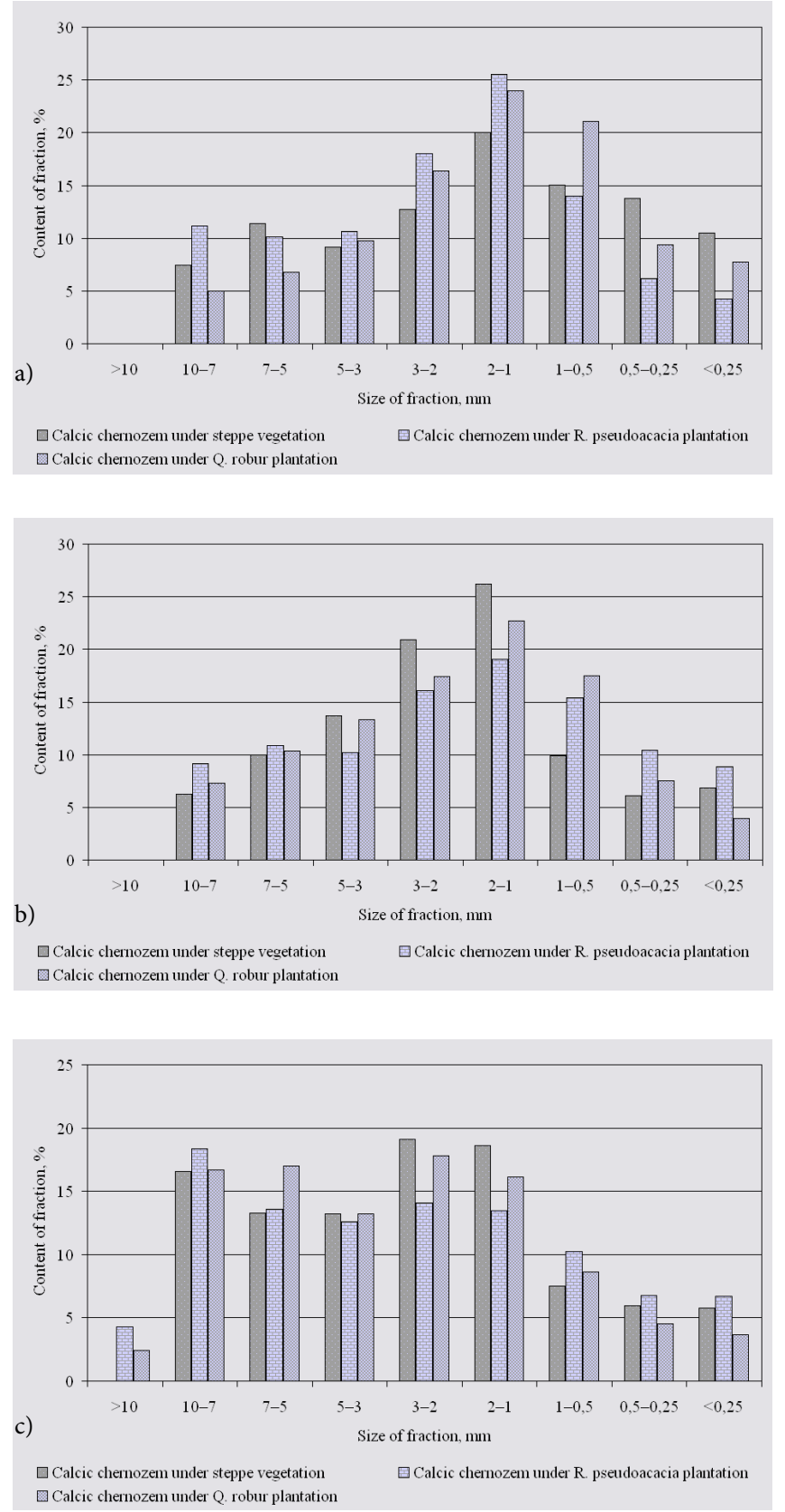

Fig. 2. Aggregate size distribution of the soils studied: a - horizon $0-20 \mathrm{~cm}$; b - horizon 20-40 cm; c - horizon 40-60 cm. found in chernozem under steppe vegetation and the minimum content (19.1\%) of that was found in chernozem under black locust plantation (Fig. 2b). At a depth of 40-60 cm, aggregate fraction 3-2 $\mathrm{mm}$ predominated in chernozem under steppe vegetation (19.1\%) and in chernozem under common oak plantation (17.8\%) (Fig. 2c). In this depth of chernozem under black locust plantation, $10-7 \mathrm{~mm}$ aggregate fraction dominated (18.4\%). Maximum contents of $10-7 \mathrm{~mm}$ aggregate fraction (17.9 and $28.1 \%$, respectively) were found in the layer of $60-80 \mathrm{~cm}$ in chernozem under black locust and common oak plantations (Fig. 2d). In the same layer of chernozem under steppe vegetation, 7-5 mm aggregate fraction predominated (21.9\%). Maximum contents of 10-7 $\mathrm{mm}$ aggregate size fraction (16.8 and $18.6 \%$, respectively) were found in the layer of $80-100 \mathrm{~cm}$ in chernozem under black locust and common oak plantations (Fig. 2e). In the same layer of chernozem under steppe vegetation, $2-1 \mathrm{~mm}$ aggregate fraction predominated (24.0\%). Additionally, in this soil, in all the selected layers, there was no agg- 
regate fraction $>10 \mathrm{~mm}$ in size. In chernozems under black locust and oak plantations, this fraction was present in layers of 40-60, $60-80$, and $80-100 \mathrm{~cm}$.

The growth of Robinia pseudoacacia trees contributed to an increase (5\%) in the content of $2-1 \mathrm{~mm}$ fraction units in the soil layer of 0-20 cm. Macroaggregates of fraction $>10$ $\mathrm{mm}$ were also present in chernozem under black locust plantation at a depth of $40-60,60-80$, and $80-100$ $\mathrm{cm}$; these macroaggregates were completely absent in chernozem profile under steppe vegetation. In these soil layers, increase in the content of aggregates $10-7$ $\mathrm{mm}$ in size was present. Content of aggregates of the fraction $<0.25 \mathrm{~mm} \mathrm{dec}$ reased with depth in chernozem under steppe vege-
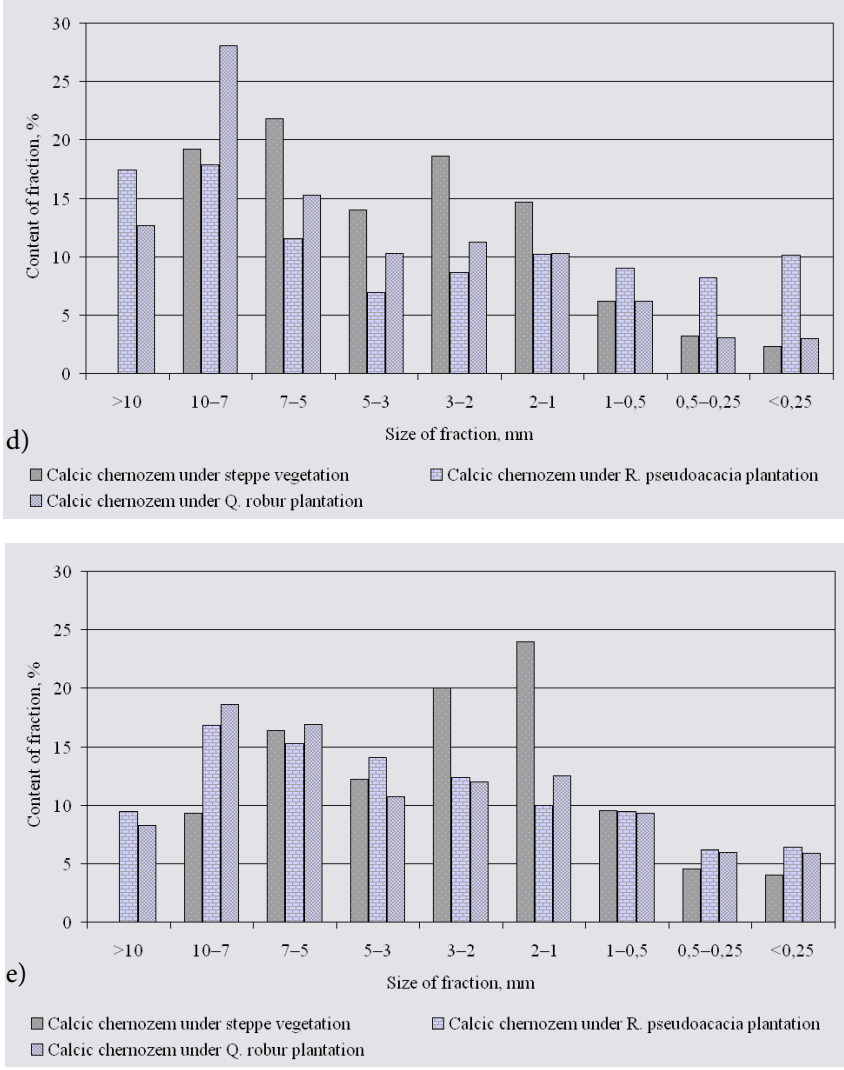

Fig. 2. Aggregate size distribution of the soils studied: $d$ - horizon $60-80$ $\mathrm{cm}$; e - horizon $80-100 \mathrm{~cm}$. tation and increased with depth in chernozem under black locust planting. The growth of Quercus robur trees also contributed to a certain increase (by 4\%) in the content of aggregate fraction of $2-1 \mathrm{~mm}$ in chernozem at a depth $0-20$ $\mathrm{cm}$ compared to chernozem under steppe vegetation. Macroaggregates of fraction $>10 \mathrm{~mm}$ in size were also present in chernozem under common oak plantation at a depth of 40-60, $60-80$, and $80-100 \mathrm{~cm}$; these macroaggregates were completely absent in chernozem under steppe vegetation. Increase in the content of aggregates of $10-7 \mathrm{~mm}$ fraction was observed in $60-80$ and $80-100 \mathrm{~cm}$ depth of chernozem under oak plantation. The content of aggregates of fraction $<0.25 \mathrm{~mm}$ decreased with depth, as well as in chernozem under steppe vegetation.

\section{Effect of forest plantations on the physical properties of chernozem}

Gu et al. (2019) reported that the volume density values should be taken as one of the indicators to assess the effect of vegetation restoration process on the physical properties of the 
$\mathrm{T}$ a b l e 2. Physical properties of the soils studied $(\mathrm{x} \pm \mathrm{SD}), \mathrm{n}=3$.

\begin{tabular}{|c|c|c|c|}
\hline \multirow{2}{*}{$\begin{array}{c}\text { Depth, } \\
\text { cm }\end{array}$} & \multicolumn{3}{|c|}{ Name of soil } \\
\hline & $\begin{array}{l}\text { Calcic chernozem under steppe } \\
\text { vegetation }\end{array}$ & $\begin{array}{l}\text { Calcic chernozem under Robinia } \\
\text { pseudoacacia plantation }\end{array}$ & $\begin{array}{c}\text { Calcic chernozem under Quercus } \\
\text { robur plantation }\end{array}$ \\
\hline \multicolumn{4}{|c|}{ Bulk density, $\mathrm{g} / \mathrm{cm}^{3}$} \\
\hline $0-20$ & $1.09 \pm 0.038^{\mathrm{a}}$ & $1.25 \pm 0.046^{\mathrm{ab}}$ & $1.18 \pm 0.061^{\mathrm{a}}$ \\
\hline $20-40$ & $1.16 \pm 0.031^{\mathrm{a}}$ & $1.35 \pm 0.055^{\mathrm{ab}}$ & $1.25 \pm 0.042^{\mathrm{a}}$ \\
\hline $40-60$ & $1.35 \pm 0.051^{\mathrm{a}}$ & $1.42 \pm 0.079^{\mathrm{a}}$ & $1.45 \pm 0.047^{\mathrm{a}}$ \\
\hline $60-80$ & $1.54 \pm 0.095^{\mathrm{a}}$ & $1.50 \pm 0.057^{\mathrm{a}}$ & $1.52 \pm 0.068^{\mathrm{a}}$ \\
\hline $80-100$ & $1.66 \pm 0.040^{\mathrm{a}}$ & $1.61 \pm 0.060^{\mathrm{a}}$ & $1.60 \pm 0.071^{\mathrm{a}}$ \\
\hline \multicolumn{4}{|c|}{ Particle density, $\mathrm{g} / \mathrm{cm}^{3}$} \\
\hline $0-20$ & $2.31 \pm 0.113^{\mathrm{a}}$ & $2.45 \pm 0.055^{\mathrm{a}}$ & $2.36 \pm 0.072^{\mathrm{a}}$ \\
\hline $20-40$ & $2.42 \pm 0.066^{\mathrm{a}}$ & $2.51 \pm 0.089^{\mathrm{a}}$ & $2.48 \pm 0.055^{\mathrm{a}}$ \\
\hline $40-60$ & $2.59 \pm 0.056^{\mathrm{a}}$ & $2.58 \pm 0.056^{\mathrm{a}}$ & $2.59 \pm 0.046^{\mathrm{a}}$ \\
\hline $60-80$ & $2.63 \pm 0.057^{\mathrm{a}}$ & $2.65 \pm 0.035^{\mathrm{a}}$ & $2.67 \pm 0.096^{\mathrm{a}}$ \\
\hline $80-100$ & $2.66 \pm 0.036^{\mathrm{a}}$ & $2.68 \pm 0.066^{\mathrm{a}}$ & $2.69 \pm 0.090^{\mathrm{a}}$ \\
\hline \multicolumn{4}{|c|}{ Total porosity, \% } \\
\hline $0-20$ & $52.6 \pm 1.77^{\mathrm{a}}$ & $48.9 \pm 2.71^{\mathrm{a}}$ & $50.0 \pm 2.59^{\mathrm{a}}$ \\
\hline $20-40$ & $52.2 \pm 1.60^{\mathrm{a}}$ & $46.0 \pm 3.24^{\mathrm{a}}$ & $49.5 \pm 2.80^{\mathrm{a}}$ \\
\hline $40-60$ & $48.0 \pm 3.05^{\mathrm{a}}$ & $45.0 \pm 2.13^{\mathrm{a}}$ & $44.1 \pm 2.07^{\mathrm{a}}$ \\
\hline $60-80$ & $41.5 \pm 4.21^{\mathrm{a}}$ & $43.3 \pm 2.87^{\mathrm{a}}$ & $42.9 \pm 4.01^{\mathrm{a}}$ \\
\hline $80-100$ & $37.6 \pm 1.93^{\mathrm{a}}$ & $40.0 \pm 3.69^{\mathrm{a}}$ & $40.7 \pm 2.86^{\mathrm{a}}$ \\
\hline
\end{tabular}

Notes: different letters denote the sets within the indicator range that differ significantly from each other according to the results of the Tukey test with Bonferroni correction; differences between the sets were considered significant at $p<0.05 ; \mathrm{SD}-$ standard deviation.

soil. This is explained by the fact that even a slight increase in soil density has a significant negative effect on the growth and development of tree species, particularly oaks (Bejarano et al., 2010; Cambi et al., 2018; Kormanek et al., 2015).

The lowest values of density and particle density ( 1.09 and $\left.2.31 \mathrm{~g} / \mathrm{cm}^{3}\right)$ at a depth of $0-20$ $\mathrm{cm}$ were common in chernozem under steppe vegetation and the maximum values $(1.25$ and $2.45 \mathrm{~g} / \mathrm{cm}^{3}$ ) in chernozem under black locust planting (Table 2). As expected, the maximum value of total porosity (52.6\%) was observed in chernozem under steppe vegetation and the minimum value (48.9\%) in chernozem under black locust planting. According to these values, the content of chernozem under oak plantation was average between chernozem under steppe vegetation and chernozem under black locust plantation. At a depth of $20-40 \mathrm{~cm}$, the lowest values of density and particle density and the maximum value of total porosity were found in chernozem under steppe vegetation. In this depth, as in the depth of $0-20 \mathrm{~cm}$, the maximum values of density and particle density and minimum value of total porosity were characteristic of chernozem under black locust plantation. At the same time, significant differences in the layers of 0-20 and 20-40 cm were found only between the values of density of chernozem under steppe vegetation and chernozem under black locust plantation. At a depth of $40-60 \mathrm{~cm}$, the minimum value of density $\left(1.35 \mathrm{~g} / \mathrm{cm}^{3}\right)$ and the maximum 
total porosity value $(48.0 \%)$ were also found in chernozem under steppe vegetation, while the studied soils did not differ in terms of particle density values. In the layer of $60-80 \mathrm{~cm}$, the maximum density value $\left(1.54 \mathrm{~g} / \mathrm{cm}^{3}\right)$ was found in chernozem under steppe vegetation and the minimum density value $\left(1.50 \mathrm{~g} / \mathrm{cm}^{3}\right)$ in chernozem under black locust plantation. Maximum value of particle density $\left(2.67 \mathrm{~g} / \mathrm{cm}^{3}\right)$ in this layer was found in chernozem under common oak plantation. Maximum density and minimum total porosity $\left(1.54 \mathrm{~g} / \mathrm{cm}^{3}\right.$ and $41.5 \%$, respectively) were observed under the steppe vegetation. A sharp increase in density was observed in the layer of $80-100 \mathrm{~cm}$, the maximum value of which $\left(1.66 \mathrm{~g} / \mathrm{cm}^{3}\right)$ was found in chernozem under steppe vegetation. The maximum values of particle density were found in chernozem under black locust plantation and oak plantation. The maximum value of total porosity $(40.7 \%)$ was observed in chernozem under oak plantation.

In general, increase in density and particle density values with a regular decrease in total porosity values of the lower layers was observed in the soil studied, which is explained by a decrease in organic carbon content with depth and, as a consequence, by deterioration in the structural and aggregate composition (Li, Shao, 2006; Li et al., 2012).

The soils studied had no significant decrease in density and increase in total porosity of chernozem under steppe vegetation as a result of the influence of Robinia pseudoacacia and Quercus robur plantations, which is not entirely consistent with the results obtained by other authors (Jiao et al., 2011; Li et al., 2012; Zhang Q. et al., 2017; Zhang X. et al., 2018). This fact can be explained by the reason that initially, the plantings were set on fairly fertile soil rather than eroded one, as pointed out by the above-mentioned authors. Significant reduction in the abundance of herbaceous vegetation under Robinia pseudoacacia plantation and especially under Quercus robur plantation was another factor that could contribute to some increase in density and decrease in total porosity. It should be noted that all the soils studied are characterized by physical properties favorable for the growth and development of woody and herbaceous plants.

\section{Effect of forest plantations on soil chemical properties and nutrient content}

Within $0-20 \mathrm{~cm}$ depth, the maximum content of soil organic carbon $(2.11 \%)$ was found in chernozem under common oak planting and the minimum $(1.35 \%)$ in chernozem under black locust planting (Table 3$)$. Maximum cation exchange capacity $(44.98 \mathrm{cmol} / 100 \mathrm{~g}$ ) was observed in chernozem under steppe vegetation and minimum $(29.55 \mathrm{cmol} / 100 \mathrm{~g})$ in chernozem under black locust plantation. Chernozem under steppe vegetation and chernozem under black locust plantation were characterized by a higher $\mathrm{pH}$ value compared with chernozem under common oak plantation, which can be explained by the release of organic acids during oak litter decomposition. This also explains the maximum value of hydrolytic soil acidity in chernozem under common oak plantation and its minimum value in chernozem under steppe vegetation. Chernozem under steppe vegetation and chernozem under black locust plantation were significantly different with lesser dry residue values compared with chernozem under common oak plantation, which can be explained by the increased ability of oak to capture and precipitate pulverous particles from the air that are released by steppe soil erosion, compared to black locust and steppe vegetation that have lesser ability to retain the dust. 
T a b l e 3. Chemical properties of the soils studied ( $x \pm \mathrm{SD})$.

\begin{tabular}{|c|c|c|c|}
\hline \multirow{2}{*}{$\begin{array}{c}\text { Depth, } \\
\text { cm }\end{array}$} & \multicolumn{3}{|c|}{ Name of soil } \\
\hline & $\begin{array}{c}\text { Calcic chernozem under steppe } \\
\text { vegetation }\end{array}$ & $\begin{array}{l}\text { Calcic chernozem under Robinia } \\
\text { pseudoacacia plantation }\end{array}$ & $\begin{array}{l}\text { Calcic chernozem under Quercus } \\
\text { robur plantation }\end{array}$ \\
\hline \multicolumn{4}{|c|}{ Soil organic carbon, $\%$} \\
\hline $0-20$ & $2.03 \pm 0.084^{\mathrm{a}}$ & $1.35 \pm 0.067^{b}$ & $2.11 \pm 0.064^{\mathrm{a}}$ \\
\hline $20-40$ & $1.49 \pm 0.057^{\mathrm{a}}$ & $0.70 \pm 0.047^{b}$ & $2.04 \pm 0.072^{c}$ \\
\hline $40-60$ & $0.59 \pm 0.059^{\mathrm{a}}$ & $0.33 \pm 0.056^{\mathrm{b}}$ & $1.18 \pm 0.068^{c}$ \\
\hline $60-80$ & $0.31 \pm 0.051^{\mathrm{a}}$ & $0.20 \pm 0.040^{\mathrm{a}}$ & $0.54 \pm 0.046^{\mathrm{b}}$ \\
\hline $80-100$ & $0.27 \pm 0.047^{\mathrm{a}}$ & $0.16 \pm 0.050^{\mathrm{a}}$ & $0.26 \pm 0.052^{\mathrm{a}}$ \\
\hline \multicolumn{4}{|c|}{ Cation exchange capacity, cmol/100 g } \\
\hline $0-20$ & $44.98 \pm 3.391^{\mathrm{a}}$ & $29.55 \pm 3.869^{\mathrm{a}}$ & $36.51 \pm 3.183^{\mathrm{ab}}$ \\
\hline $20-40$ & $35.85 \pm 2.458^{\mathrm{a}}$ & $28.69 \pm 3.097^{\mathrm{a}}$ & $31.54 \pm 3.491^{\mathrm{a}}$ \\
\hline $40-60$ & $26.57 \pm 2.234^{\mathrm{a}}$ & $23.94 \pm 2.547^{\mathrm{a}}$ & $42.21 \pm 3.269^{\mathrm{b}}$ \\
\hline $60-80$ & $30.00 \pm 2.310^{\mathrm{a}}$ & $19.20 \pm 2.560^{\mathrm{b}}$ & $21.40 \pm 3.350^{\mathrm{ab}}$ \\
\hline $80-100$ & $34.89 \pm 2.002^{\mathrm{a}}$ & $15.43 \pm 2.844^{\mathrm{b}}$ & $40.28 \pm 2.449^{\mathrm{a}}$ \\
\hline \multicolumn{4}{|c|}{$\mathrm{pH}\left(\mathrm{H}_{2} \mathrm{O}\right)$} \\
\hline $0-20$ & $7.65 \pm 0.122^{\mathrm{a}}$ & $7.64 \pm 0.159^{\mathrm{a}}$ & $7.23 \pm 0.146^{\mathrm{a}}$ \\
\hline $20-40$ & $7.67 \pm 0.098^{\mathrm{a}}$ & $7.74 \pm 0.137^{\mathrm{a}}$ & $7.16 \pm 0.114^{\mathrm{b}}$ \\
\hline $40-60$ & $7.94 \pm 0.061^{\mathrm{a}}$ & $7.80 \pm 0.110^{\mathrm{a}}$ & $7.53 \pm 0.363^{\mathrm{a}}$ \\
\hline $60-80$ & $8.07 \pm 0.053^{\mathrm{a}}$ & $7.83 \pm 0.071^{\mathrm{b}}$ & $7.97 \pm 0.097^{\mathrm{ab}}$ \\
\hline $80-100$ & $8.26 \pm 0.103^{\mathrm{a}}$ & $7.85 \pm 0.119^{\mathrm{b}}$ & $8.15 \pm 0.091^{\mathrm{ab}}$ \\
\hline \multicolumn{4}{|c|}{ Hydrolytic soil acidity, $\mathrm{mmol} / 100 \mathrm{~g}$} \\
\hline $0-20$ & $0.20 \pm 0.046^{\mathrm{a}}$ & $0.24 \pm 0.040^{\mathrm{a}}$ & $0.55 \pm 0.038^{b}$ \\
\hline $20-40$ & $0.13 \pm 0.021^{\mathrm{a}}$ & $0.20 \pm 0.026^{\mathrm{a}}$ & $0.64 \pm 0.067^{b}$ \\
\hline $40-60$ & $0.08 \pm 0.032^{\mathrm{a}}$ & $0.14 \pm 0.031^{\mathrm{a}}$ & $0.44 \pm 0.047^{\mathrm{b}}$ \\
\hline $60-80$ & $0.07 \pm 0.026^{\mathrm{a}}$ & $0.11 \pm 0.021^{\mathrm{a}}$ & $0.29 \pm 0.025^{\mathrm{b}}$ \\
\hline $80-100$ & $0.05 \pm 0.031^{\mathrm{a}}$ & $0.08 \pm 0.015^{\mathrm{a}}$ & $0.16 \pm 0.035^{\mathrm{a}}$ \\
\hline \multicolumn{4}{|c|}{ Dry residue, ppm } \\
\hline $0-20$ & $34.43 \pm 2.050^{\mathrm{a}}$ & $37.79 \pm 2.606^{\mathrm{a}}$ & $50.05 \pm 2.734^{\mathrm{b}}$ \\
\hline $20-40$ & $29.90 \pm 3.017^{a}$ & $29.20 \pm 2.096^{\mathrm{a}}$ & $46.00 \pm 2.234^{\mathrm{b}}$ \\
\hline $40-60$ & $35.30 \pm 2.252^{\mathrm{a}}$ & $30.64 \pm 2.262^{\mathrm{a}}$ & $47.83 \pm 3.669^{\mathrm{b}}$ \\
\hline $60-80$ & $35.81 \pm 2.388^{\mathrm{a}}$ & $27.43 \pm 2.538^{b}$ & $58.83 \pm 3.320^{c}$ \\
\hline $80-100$ & $36.07 \pm 2.268^{\mathrm{a}}$ & $25.17 \pm 2.686^{b}$ & $68.03 \pm 3.900^{c}$ \\
\hline
\end{tabular}

Notes: different letters denote the sets within the indicator range that differ significantly from each other according to the results of the Tukey test with Bonferroni correction; differences between the sets were considered significant at $p<0.05 ; \mathrm{SD}-$ standard deviation.

At a depth of 20-40 cm, values of carbon content in chernozem under the common oak stands were significantly the highest, while the minimum content of carbon was in chernozem under the black locust plantation. The maximum value of cation exchange capacity $(35.85 \mathrm{cmol} / 100 \mathrm{~g})$ was found in chernozem under steppe vegetation and the minimum value $(28.69 \mathrm{cmol} / 100 \mathrm{~g})$ of that was found under the black locust plantation. Significant decrease in $\mathrm{pH}$ values was observed in chernozem under common oak plantation in com- 
T a b l e 4. Content $\left(\mathrm{NH}_{4}+\mathrm{NO}_{3} ; \mathrm{P}_{2} \mathrm{O}_{5} ; \mathrm{K}_{2} \mathrm{O}\right)$ of nitrogen, phosphorus, and potassium in the soil studied $(\mathrm{x} \pm \mathrm{SD})$, $\mathrm{n}=3$.

\begin{tabular}{|c|c|c|c|}
\hline \multirow[b]{2}{*}{$\begin{array}{l}\text { Depth, } \\
\text { cm }\end{array}$} & \multicolumn{3}{|c|}{ Name of soil } \\
\hline & $\begin{array}{c}\text { Calcic chernozem under steppe } \\
\text { vegetation }\end{array}$ & $\begin{array}{c}\text { Calcic chernozem under Robinia } \\
\text { pseudoacacia plantation }\end{array}$ & $\begin{array}{c}\text { Calcic chernozem under Quercus } \\
\text { robur plantation }\end{array}$ \\
\hline \multicolumn{4}{|c|}{$\mathrm{N}, \mathrm{mg} / \mathrm{kg}$} \\
\hline $0-20$ & $75.24 \pm 3.042^{\mathrm{a}}$ & $60.73 \pm 2.702^{b}$ & $74.96 \pm 3.046^{\mathrm{a}}$ \\
\hline $20-40$ & $47.28 \pm 3.874^{\mathrm{a}}$ & $32.63 \pm 2.550^{\mathrm{b}}$ & $69.91 \pm 2.628^{c}$ \\
\hline $40-60$ & $15.63 \pm 2.510^{\mathrm{a}}$ & $21.88 \pm 1.675^{a}$ & $44.68 \pm 2.123^{b}$ \\
\hline $60-80$ & $9.67 \pm 3.215^{\mathrm{a}}$ & $17.35 \pm 2.145^{\mathrm{a}}$ & $15.48 \pm 1.115^{\mathrm{a}}$ \\
\hline $80-100$ & $6.87 \pm 1.054^{\mathrm{a}}$ & $14.18 \pm 1.509^{b}$ & $8.41 \pm 1.039^{\mathrm{a}}$ \\
\hline \multicolumn{4}{|c|}{$\mathrm{P}, \mathrm{mg} / \mathrm{kg}$} \\
\hline $0-20$ & $45.70 \pm 2.696^{\mathrm{a}}$ & $25.64 \pm 2.758^{\mathrm{b}}$ & $49.20 \pm 2.342^{\mathrm{a}}$ \\
\hline $20-40$ & $39.54 \pm 2.342^{\mathrm{a}}$ & $29.13 \pm 1.946^{\mathrm{b}}$ & $63.39 \pm 2.093^{c}$ \\
\hline $40-60$ & $37.17 \pm 2.228^{\mathrm{a}}$ & $38.07 \pm 2.663^{\mathrm{a}}$ & $62.18 \pm 1.487^{\mathrm{b}}$ \\
\hline $60-80$ & $37.83 \pm 1.938^{\mathrm{a}}$ & $38.27 \pm 2.197^{\mathrm{a}}$ & $51.44 \pm 1.448^{\mathrm{b}}$ \\
\hline $80-100$ & $38.21 \pm 2.909^{\mathrm{a}}$ & $38.14 \pm 1.642^{\mathrm{a}}$ & $50.68 \pm 1.997^{\mathrm{b}}$ \\
\hline \multicolumn{4}{|c|}{$\mathrm{K}, \mathrm{mg} / \mathrm{kg}$} \\
\hline $0-20$ & $138.52 \pm 3.259^{\mathrm{a}}$ & $107.19 \pm 4.052^{\mathrm{b}}$ & $98.03 \pm 2.312^{\mathrm{b}}$ \\
\hline $20-40$ & $83.85 \pm 2.303^{a}$ & $59.37 \pm 2.587^{\mathrm{b}}$ & $62.68 \pm 2.871^{\mathrm{b}}$ \\
\hline $40-60$ & $79.52 \pm 2.477^{\mathrm{a}}$ & $54.62 \pm 3.293^{\mathrm{b}}$ & $79.03 \pm 3.257^{\mathrm{a}}$ \\
\hline $60-80$ & $75.09 \pm 3.070^{\mathrm{a}}$ & $60.26 \pm 2.422^{b}$ & $64.92 \pm 2.875^{b}$ \\
\hline $80-100$ & $72.25 \pm 2.394^{\mathrm{a}}$ & $69.64 \pm 3.325^{\mathrm{a}}$ & $70.03 \pm 2.345^{\mathrm{a}}$ \\
\hline
\end{tabular}

Notes: different letters denote the sets within the indicator range that differ significantly from each other according to the results of the Tukey test with Bonferroni correction; differences between the sets were considered significant at $p<0.05 ; \mathrm{SD}-$ standard deviation.

parison with chernozem under steppe vegetation and chernozem under black locust plantation. Also, chernozem under common oak plantation was characterized by large values of hydrolytic soil acidity and dry residue compared to chernozem under steppe vegetation and chernozem under black locust plantation.

The maximum values of soil organic carbon content (1.18\%), cation exchange capacity $(42.21 \mathrm{cmol} / 100 \mathrm{~g})$, hydrolytic soil acidity $(0.44 \mathrm{mmol} / 100 \mathrm{~g})$, and dry residue $(47.83 \mathrm{ppm})$ in chernozem under oak plantation were obtained at a depth of $40-60 \mathrm{~cm}$. The maximum $\mathrm{pH}$ value (7.94) was characteristic of chernozem under steppe vegetation.

The maximum content of soil organic carbon was found at a depth of $80-100 \mathrm{~cm}$ in chernozem under steppe vegetation and chernozem under common oak plantation $(0.27$ and $0.26 \%$, respectively). Chernozem under steppe vegetation and chernozem under common oak plantation were also characterized by increased values of cation exchange capacity and $\mathrm{pH}$ compared with chernozem under black locust plantation. The maximum values of hydrolytic soil acidity $(0.16 \mathrm{mmol} / 100 \mathrm{~g})$ and dry residue $(68.03 \mathrm{ppm})$ were found in chernozem under common oak plantation.

In general, growth of common oak has a more pronounced positive effect on the chemical properties of chernozem than the growth of black locust. This is manifested by a slight 


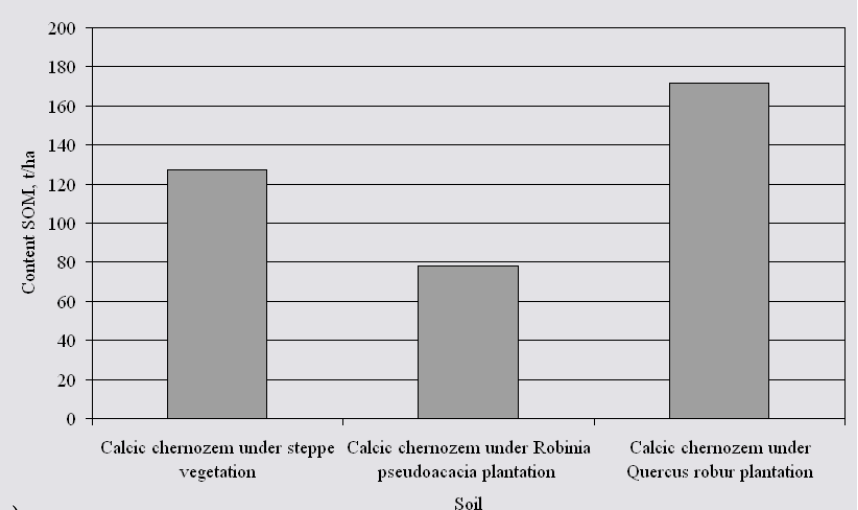

a)
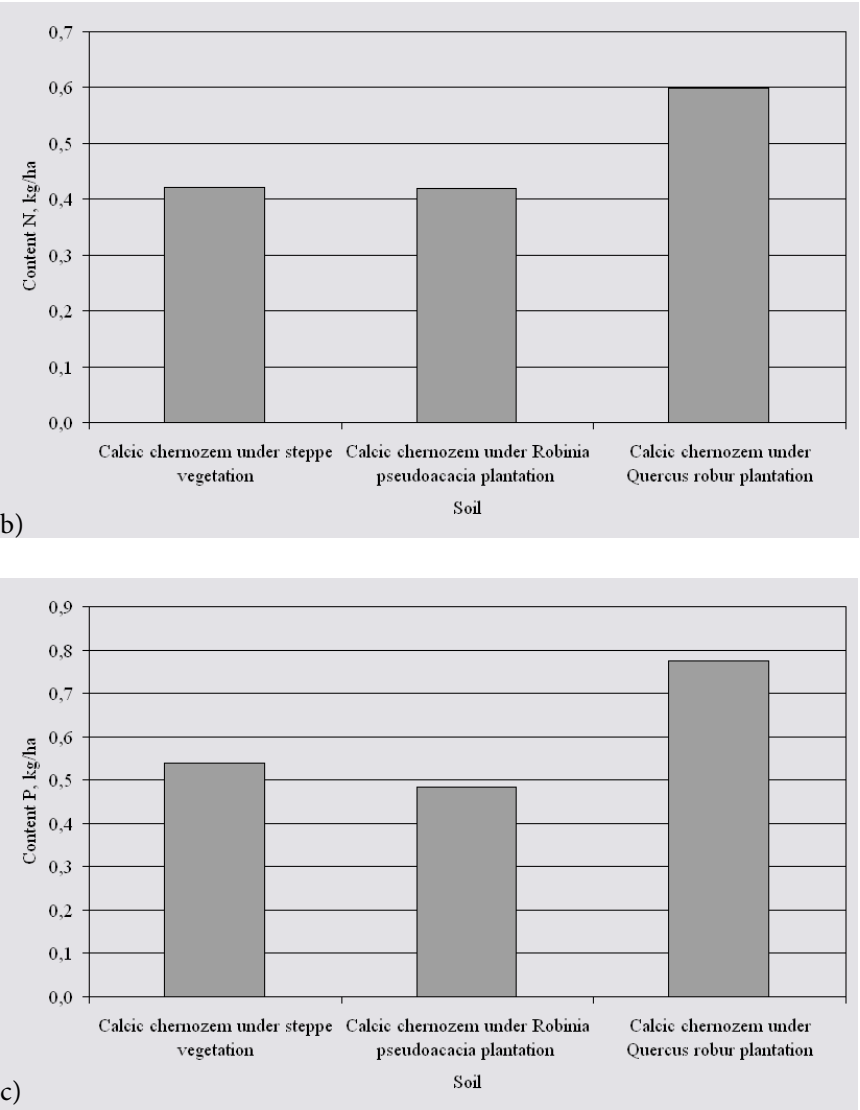

Fig. 3. Stocks of carbon (a), nitrogen (b), phosphorus (c) in the 1-m layer of the soil studied. increase in organic carbon content and an increase in cation exchange capacity of chernozem under common oak plantation compared to chernozem under steppe vegetation and chernozem under black locust plantation.

When studying the effect of black locust and oak plantings on the nutrient content in chernozem, it emerged that at a depth of $0-20 \mathrm{~cm}$, the greatest nitrogen and phosphorus reserves were found in chernozem under steppe vegetation and chernozem under oak plantation (Table 4). In chernozem under black locust plantation, the contents of nitrogen and phosphorus were significantly minimal (60.7 and $25.64 \mathrm{mg} / \mathrm{kg}$, respectively). Maximum potassium content (138.52 $\mathrm{mg} / \mathrm{kg}$ ) was found in chernozem under steppe vegetation and the minimum content $(98.03 \mathrm{mg} / \mathrm{kg})$ was found in chernozem under oak plantation.

At a depth of $20-40$ $\mathrm{cm}$, the maximum contents of nitrogen and phosphorus (69.91 and $63.39 \mathrm{mg} / \mathrm{kg}$ ) were found in chernozem under oak plantation and the minimum contents (32.63 and $29.13 \mathrm{mg} / \mathrm{kg}$ ) were found 
in chernozem under black locust plantation. As in 0-20 cm depth, significant maximum reserves of potassium were found in chernozem under steppe vegetation.

As in previous layers, the largest nitrogen and phosphorus reserves were found at a depth of 40-60 $\mathrm{cm}$ in chernozem under oak plantation (44.68 and $62.18 \mathrm{mg} / \mathrm{kg}$, respectively). The minimum values

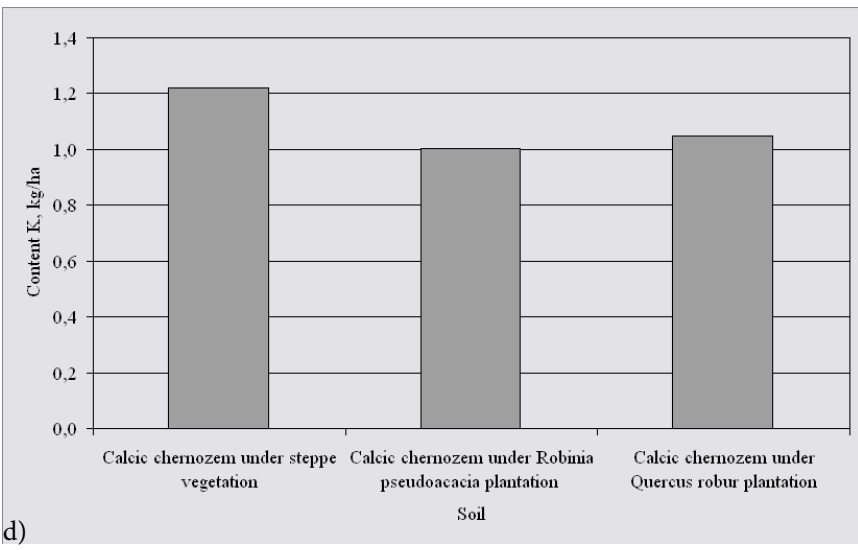

Fig. 3. Stocks of potassium (d) in the 1-m layer of the soil studied. of this nutrient content in this soil layer were found in chernozem under steppe vegetation and somewhat more values were found in chernozem under black locust plantation. In this depth, the maximum potassium content was observed in chernozem under steppe vegetation and chernozem under oak plantation (79.03 and $79.52 \mathrm{mg} / \mathrm{kg}$, respectively).

The nutrient distribution was similar at depths of $60-80$ and $80-100 \mathrm{~cm}$. The maximum nitrogen content was found in chernozem under black locust plantation and the minimum nitrogen content in chernozem under steppe vegetation. The highest values of phosphorus were associated with chernozem under common oak plantation and the lowest values were observed in chernozem under steppe vegetation and chernozem under black locust plantation. The maximum potassium deposits were found in chernozem under steppe vegetation.

For clarification the behavior of carbon, nitrogen, phosphorus, and potassium accumulation under the influence of Robinia pseudoacacia and Quercus robur plantations, storages of these nutrients were calculated by soil layers 10 and $100 \mathrm{~cm}$ in thickness.

Within the $10-\mathrm{cm}$ layer, the maximum reserves of carbon, nitrogen, and phosphorus (24.9 t/ha, $0.088 \mathrm{~kg} / \mathrm{ha}$, and $0.058 \mathrm{~kg} / \mathrm{ha}$, respectively) were found in chernozem under $\mathrm{Q}$. robur, slightly less $(22.2 \mathrm{t} / \mathrm{ha}, 0.082 \mathrm{~kg} / \mathrm{ha}$, and $0.050 \mathrm{~kg} / \mathrm{ha}$, respectively) reserves in chernozem under steppe vegetation, and the least reserves $(16.8 \mathrm{t} / \mathrm{ha}, 0.076 \mathrm{~kg} / \mathrm{ha}$, and $0.032 \mathrm{~kg} / \mathrm{ha}$, respectively) were found in chernozem under Robinia pseudoacacia. The maximum amount of potassium $(0.151 \mathrm{~kg} / \mathrm{ha})$ was detected in chernozem under steppe vegetation, lesser $(0.134$ $\mathrm{kg} / \mathrm{ha}$ ) amount in chernozem under R. pseudoacacia plantation, and the minimum $(0.116 \mathrm{~kg} /$ ha) of that was found in chernozem under Quercus robur plantation.

At a depth of $100 \mathrm{~cm}$, the highest carbon content (171.7 t/ha) was found in chernozem under Q. robur plantation and the minimum content $(78.0 \mathrm{t} / \mathrm{ha}$ ) was detected in chernozem under Robinia pseudoacacia plantation. Chernozem under steppe vegetation occupied an intermediate position in terms of carbon deposit values (Fig. 3a). The maximum contents of nitrogen $(0.598$ $\mathrm{kg} / \mathrm{ha}$ ) as well as carbon were found in chernozem under Quercus robur plantation (Fig. 3b). 
The values of nitrogen deposit in chernozem under steppe vegetation were similar to those in chernozem under Robinia pseudoacacia plantation $(0.421$ and $0.419 \mathrm{~kg} / \mathrm{ha}$, respectively). The maximum reserve of phosphorus $(0.775 \mathrm{~kg} / \mathrm{ha})$ was found in chernozem under Quercus robur plantation (Fig. 3c) and the minimum reserve $(0.483 \mathrm{~kg} / \mathrm{ha})$ in chernozem under Robinia pseudoacacia plantation. Chernozem under steppe vegetation occupied an intermediate position regarding the values of phosphorus deposits. Maximum potassium content $(1.222 \mathrm{~kg} / \mathrm{ha})$ was detected in chernozem under steppe vegetation (Fig. $3 \mathrm{~d})$. Chernozems under Quercus robur and Robinia pseudoacacia plantations were characterized by slightly smaller reserves of potassium (1.049 and $1.002 \mathrm{~kg} / \mathrm{ha}$, respectively) compared with chernozems under steppe vegetation.

\section{Conclusion}

The effect of R. pseudoacacia and Quercus robur plantations on aggregate size distribution of chernozem was evident in the increase in content of aggregate fraction of 2-1 $\mathrm{mm}$ and in formation of aggregate fraction $>10 \mathrm{~mm}$, which were absent in chernozem under steppe vegetation. The changes in the physical properties of chernozem were evidenced by a slight increase in their density and particle density, as well as a decrease in total porosity, but these differences were more pronounced in the upper layers of chernozem under Robinia pseudoacacia plantation than in chernozem under Quercus robur plantation. Changes in the chemical properties of chernozem were associated with a decrease in carbon content under the growth of Robinia pseudoacacia and an increase in carbon content under the growth of Quercus robur. Effect of plantations' growth on the value of cation exchange capacity was manifested in the same manner. The growth of Robinia pseudoacacia and Quercus robur plantations was accompanied by a certain decrease in $\mathrm{pH}$ level, increase in hydrolytic soil acidity, and dry residue of chernozem. Effect of Robinia pseudoacacia planting was pronounced as evidence by a decrease in carbon, nitrogen, and phosphorus content in chernozem. By contrast, the influence of Quercus robur growth led to accumulation of these nutrients. Growth of Robinia pseudoacacia and Quercus robur plantations led to a decrease in potassium reserves in chernozem, which may indicate its active uptake by these woody species. In general, Q. robur planting is characterized by a large positive effect on the physical and chemical properties of chernozem than Robinia pseudoacacia planting. The findings obtained serve as a ground for making a recommendation for growing $Q$. robur plantations in the conditions of the steppe zone of Ukraine in order to improve the zonal chernozems' state and fertility.

\section{References}

Amundson, R., Berhe, A.A., Hopmans, J.W., Olson, C., Sztein, A.E. \& Sparks D.L. (2015). Soil and human security in the 21st century. Science, 348(6235), 1261071. DOI: 10.1126/science.1261071.

An, S., Mentler, A., Mayer, H. \& Blum W.E.H. (2010). Soil aggregation, aggregate stability, organic carbon and nitrogen in different soil aggregate fractions under forest and shrub vegetation on the Loess Plateau, China. Catena, 81(3), 226-233. DOI: 10.1016/j.catena.2010.04.002.

Baranovski, B., Roschina, N., Karmyzova, L. \& Ivanko I. (2018). Comparison of commonly used ecological scales with the Belgard Plant Ecomorph System. Biosystems Diversity, 26(4), 286-291. DOI: 10.15421/011843.

Bárcena, T.G., Gundersen, P. \& Vesterdal L. (2014). Afforestation effects on SOC in former cropland: Oak and spruce chronosequences resampled after 13 years. Global Change Biology, 20(9), 2938-2952. DOI: 10.1111/gcb.12608. 
Bejarano, M.D., Villar, R., Murillo, A.M. \& Quero J.L. (2010). Effects of soil compaction and light on growth of Quercus pyrenaica Willd. (Fagaceae) seedlings. Soil Tillage Res., 110(1), 108-114. DOI: 10.1016/j.still.2010.07.008.

Berthrong, S.T., Piñeiro, G., Jobbágy, E.G. \& Jackson R.B. (2012). Soil C and N changes with afforestation of grasslands across gradients of precipitation and plantation age. Ecol. Appl., 22(1), 76-86. DOI: 10.1890/10-2210.1.

Bonfante, A., Terribile, F. \& Bouma J. (2019). Refining physical aspects of soil quality and soil health when exploring the effects of soil degradation and climate change on biomass production: An Italian case study. Soil, 5(1), 1-14. DOI: 10.5194/soil-5-1-2019.

Boussougou, I.N.M., Brais, S., Tremblay, F. \& Gaussiran S. (2010). Soil quality and tree growth in plantations of forest and agricultural origin. Soil Sci. Soc. Am. J., 74(3), 993-1000. DOI: 10.2136/sssaj2009.0264.

Brygadyrenko, V.V. (2014). Influence of soil moisture on litter invertebrate community structure of pine forests of the steppe zone of Ukraine. Folia Oecologica, 41(1), 8-16.

Brygadyrenko, V.V. (2015). Community structure of litter invertebrates of forest belt ecosystems in the Ukrainian steppe zone. International Journal of Environmental Research, 9(4), 1183-1192. DOI: 10.22059/IJER.2015.1008.

Brygadyrenko, V.V. (2016). Effect of canopy density on litter invertebrate community structure in pine forests. Ekológia (Bratislava), 35(1), 90-102. DOI: 10.1515/eko-2016-0007.

Cambi, M., Mariotti, B., Fabiano, F., Maltoni, A., Tani, A., Foderi, C., Laschi, A. \& Marchi E. (2018). Early response of Quercus robur seedlings to soil compaction following germination. Land Degrad. Dev., 29(4), 916-925. DOI: 10.1002/ldr.2912.

Carter, M.R. \& Gregorich E.G. (2008). Soil sampling and methods of analysis. Boca Raton: CRC Press.

Chaplot, V. \& Cooper M. (2015). Soil aggregate stability to predict organic carbon outputs from soils. Geoderma, 243-244, 205-213. DOI: 10.1016/j.geoderma.2014.12.013.

Chappell, A., Webb, N.P., Leys, J.F., Waters, C.M., Orgill, S. \& Eyres M.J. (2019). Minimising soil organic carbon erosion by wind is critical for land degradation neutrality. Environmental Science and Policy, 93, 43-52. DOI: 10.1016/j.envsci.2018.12.020.

Clark, J.D. \& Johnson A.H. (2011). Carbon and nitrogen accumulation in post-agricultural forest soils of western New England. Soil Sci. Soc. Am. J., 75(4), 1530-1542. DOI: 10.2136/sssaj2010.0180.

Day, S.D., Wiseman, P.E., Dickinson, S.B. \& Harris J.R. (2010). Tree root ecology in the urban environment and implications for a sustainable rhizosphere. Arboriculture and Urban Forestry, 36, 193-205.

De Carvalho Silva Neto, E., Pereira, M.G., Fernandes, J.C.F. \& De Andrade Corrêa Neto T. (2016). Aggregate formation and soil organic matter under different vegetation types in Atlantic Forest from Southeastern Brazil. Semina: Ciencias Agrarias, 37(6), 3927-3940. DOI: 10.5433/1679-0359.2016v37n6p3927.

Edmondson, J.L., O’Sullivan, O.S., Inger, R., Potter, J., McHugh, N., Gaston, K.J. \& Leake J.R. (2014). Urban tree effects on soil organic carbon. PLoS ONE, 9(7), e101872. DOI: 10.1371/journal.pone.0101872.

Foote, R.L. \& Grogan P. (2010). Soil carbon accumulation during temperate forest succession on abandoned low productivity agricultural lands. Ecosystems, 13(6), 795-812. DOI: 10.1007/s10021-010-9355-0.

Gu, C., Mu, X., Gao, P., Zhao, G., Sun, W., Tatarko, J. \& Tan X. (2019). Influence of vegetation restoration on soil physical properties in the Loess Plateau, China. Journal of Soils and Sediments, 19(2), 716-728. DOI: 10.1007/ s11368-018-2083-3.

Guidelines for soil description (2006). Rome: FAO.

Guo, L.B. \& Gifford R.M. (2002). Soil carbon stocks and land use change: a metaanalysis. Global Change Biology, 8, 345-360. DOI: 10.1046/j.1354-1013.2002.00486.x.

Gurmesa, G.A., Schmidt, I.K., Gundersen, P. \& Vesterdal L. (2013). Soil carbon accumulation and nitrogen retention traits of four tree species grown in common gardens. For. Ecol. Manag., 309, 47-57. DOI: 10.1016/j. foreco.2013.02.015.

IUSS Working Group WRB (2015). World Reference Base for Soil Resources 2014, update 2015 International soil classification system for naming soils and creating legends for soil maps.

Jiang, C., Liu, J., Zhang, H., Zhang, Z. \& Wang D. (2019). China's progress towards sustainable land degradation control: Insights from the northwest arid regions. Ecological Engineering, 127, 75-87. DOI: 10.1016/j.ecoleng.2018.11.014.

Jiang, R., Gunina, A., Qu, D., Kuzyakov, Y., Yu, Y., Hatano, R., Frimpong, K.A. \& Li M. (2019). Afforestation of loess soils: Old and new organic carbon in aggregates and density fractions. Catena, 177, 49-56. DOI: 10.1016/j. catena.2019.02.002.

Jiao, F., Wen, Z.-M. \& An S.-S. (2011). Changes in soil properties across a chronosequence of vegetation restoration on the Loess Plateau of China. Catena, 86(2), 110-116. DOI: 10.1016/j.catena.2011.03.001. 
Jobbagy, E.G. \& Jackson R.B. (2000). The vertical distribution of soil organic carbon and its relation to climate and vegetation. Ecol. Appl., 10, 423-436. DOI: 10.1890/1051-0761(2000)010[0423:TVDOSO]2.0.CO;2.

Kormanek, M., Głąb, T., Banach, J. \& Szewczyk G. (2015). Effects of soil bulk density on sessile oak Quercus petraea Liebl. seedlings. European Journal of Forest Research, 134(6), 969-979. DOI: 10.1007/s10342-015-0902-2.

Lal, R. (2004). Soil carbon sequestration impacts on global climate change and food security. Science, 304(5677), 1623-1627. DOI: 10.1126/science.1097396.

Lal, R. (2005). Forest soils and carbon sequestration. For. Ecol. Manag., 220(1-3), 242-258. DOI: 10.1016/j. foreco.2005.08.015.

Li, W., Yan, M., Qingfeng, Z. \& Zhikaun J. (2012). Effects of vegetation restoration on soil physical properties in the wind-water erosion region of the Northern Loess Plateau of China. Clean - Soil, Air, Water, 40(1), 7-15. DOI: 10.1002/clen.201100367.

Li, Y.Y. \& Shao M.A. (2006). Change of soil physical properties under long-term natural vegetation restoration in the Loess Plateau of China. J. Arid Environ., 64(1), 77-96. DOI: 10.1016/j.jaridenv.2005.04.005.

Medvedev, V.V., Plisko, I.V. \& Bigun O.N. (2014). Comparative characterization of the optimum and actual parameters of Ukrainian chernozems. Eurasian Soil Science, 47(10), 1044-1057. DOI: 10.1134/S106422931410007X.

Netsvetov, M., Prokopuk, Y., Didukh, Y. \& Romenskyy M. (2018). Climatic sensitivity of Quercus robur L. in floodplain near Kyiv under river regulation. Dendrobiology, 79, 20-33. DOI: 10.12657/denbio.079.003.

Paul, K.I., Polglase, P.J., Nyakuengama, J.G. \& Khanna P.K. (2002). Change in soil carbon following afforestation. For. Ecol. Manag., 168(1-3), 241-257. DOI: 10.1016/S0378-1127(01)00740-X.

Polláková, N., Šimanský, V. \& Kravka M.J. (2018). The influence of soil organic matter fractions on aggregates stabilization in agricultural and forest soils of selected Slovak and Czech hilly lands. Soils Sediments, 18, 2790. DOI: $10.1007 / \mathrm{s} 11368-017-1842-\mathrm{x}$.

Ritter, E., Vesterdal, L. \& Gundersen P. (2003). Changes in soil properties after afforestation of former intensively managed soils with oak and Norway spruce. Plant Soil, 249(2), 319-330. DOI: 10.1023/A:1022808410732.

Sauer, T.J., James, D.E., Cambardella, C.A. \& Hernandez-Ramirez G. (2012). Soil properties following reforestation or afforestation of marginal cropland. Plant Soil, 360(1-2), 375-390. DOI: 10.1007/s11104-012-1258-8.

Six, J., Bossuyt, H., Degryze, S. \& Denef K. (2004). A history of research on the link between (micro)aggregates, soil biota, and soil organic matter dynamics. Soil Tillage Res., 79(1), 7-31. DOI: 10.1016/j.still.2004.03.008.

Sun, D., Zhang, W., Lin, Y., Liu, Z., Shen, W., Zhou, L., Rao, X., Liu, S., Cai, X.-A., He, D. \& Fu S. (2018). Soil erosion and water retention varies with plantation type and age. For. Ecol. Manag., 422, 1-10. DOI: 10.1016/j. foreco.2018.03.048.

Ussiri, D.A.N., Lal, R. \& Jacinthe P.A. (2006). Soil properties and carbon sequestration of afforested pastures in reclaimed minesoils of Ohio. Soil Sci. Soc. Am. J., 70(5), 1797-1806. DOI: 10.2136/sssaj2005.0352.

Webb, N.P., Marshall, N.A., Stringer, L.C., Reed, M.S., Chappell, A. \& Herrick J.E. (2017). Land degradation and climate change: building climate resilience in agriculture. Frontiers in Ecology and the Environment, 15(8), 450459. DOI: $10.1002 /$ fee. 1530 .

Wiśniewski, P. \& Märker M. (2019). The role of soil-protecting forests in reducing soil erosion in young glacial landscapes of Northern-Central Poland. Geoderma, 337, 1227-1235. DOI: 10.1016/j.geoderma.2018.11.035.

Wunder, S. \& Bodle R. (2019). Achieving land degradation neutrality in Germany: Implementation process and design of a land use change based indicator. Environmental Science and Policy, 92, 46-55. DOI: 10.1016/j.envsci.2018.09.022

Zhang, Q., Shao, M., Jia, X. \& Zhang C. (2018). Understory vegetation and drought effects on soil aggregate stability and aggregate-associated carbon on the load plateau in China. Soil Sci. Soc. Am. J., 82(1), 106-114. DOI: 10.2136/sssaj2017.05.0145.

Zhang, X., Yang, Z., Zha, T., Zhang, Z., Wang, G., Zhu, Y. \& Lü Z. (2017). Changes in the physical properties of soil in forestlands after 22 years under the influence of the conversion of cropland into farmland project in Loess region, Western Shanxi Province. Shengtai Xuebao/Acta Ecologica Sinica, 37(2), 416-424. DOI: 10.5846/ stxb201507291596.

Zhang, X., Adamowski, J.F., Deo, R.C., Xu, X., Zhu, G. \& Cao J. (2018). Effects of afforestation on soil bulk density and $\mathrm{pH}$ in the Loess Plateau, China. Water (Switzerland), 10(12), 1710. DOI: 10.3390/w10121710.

Zhou, Y., Hartemink, A. E., Shi, Z., Liang, Z. \& Lu Y. (2019). Land use and climate change effects on soil organic carbon in North and Northeast China. Sci. Total Environ., 647, 1230-1238. DOI: 10.1016/j.scitotenv.2018.08.016. 